\title{
Orpheus' Argonautica: Decoding the Real Voyage of the Argonauts
}

\author{
Sofias Sotirios* \\ *Corresponding Author: Sofias Sotirios, Geodesy (National Technical University of Athens, \\ Faculty of Surveying Engineering), Gis expert (ArcGIS ESRI), author of the historical books \\ Orpheus \& Argonauts, Atlantis Of Plato, Centauri, Athens, Greece. \\ E-mail:sotosofias@yahoo.gr
}

\section{ABSTRACT}

An analytical description of the Argonautic expedition through the ancient text "Orpheus Argonautica "with the assistance of Google Earth

Keywords: Argonautica, Orpheus, Argo, Jason, Medea, Colchis, Borysthenes, Circe, Scylla, Talos

\section{INTRODUCTION}

\section{THE ARGONAUTIC VOYAGE}

Argo started its epic journey from Iolkos (present-day the city of Volos) the harbor of Minyans in the Pagasitic Bay. Jason, prince of Iolkos was the head of the expedition, Orpheus was its spiritual leader, and the Argonauts were 52 in total.

Their destination was Colchis, the colony of Iolkos in the Black Sea.

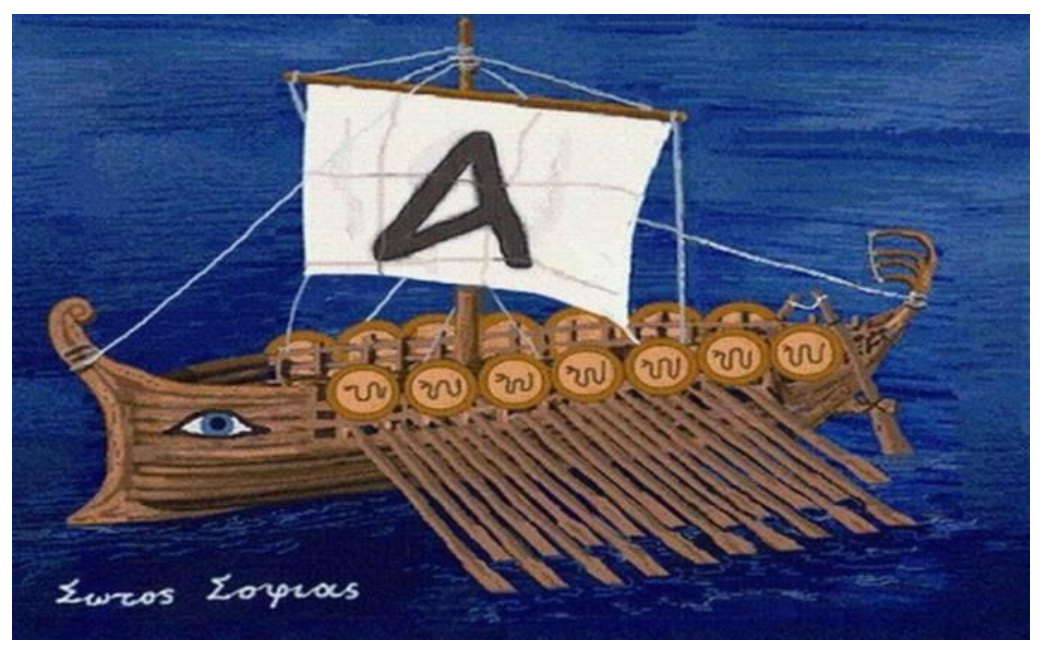

Figure1. The real Argo, in an artistic illustration designed by me. By being" Dieris (i.e. bireme boat) Sarakontoros" (i.e. meaning a ship with total 40 oars arranged in two rows of $10+10$ on both sides) the total length of the ship was reduced. This way, Argo was a very powerful ship in the open sea but also flexible while travelling through the narrow floating rivers of minor Asia's \& Central Europe's.

The first stop was at the cave of Centauri Chiron (v. 371-457), which is located at present-day Milina's Vathospilia beach, about 30 kilometers south of Volos. The Centauri were not hybrid monsters (half man and half horse) but rather professional shepherds who used a kind of spear (Kentavros in ancient greek: kentrizo ton tavro=sting the taurus) to urge the bulls- the leaders of the herb-to the plains.

They stayed there for a few hours and after they received supplies for their journey (covers, food, wine, medicine, etc) as a gift from Chiron, they came out of the golf to the open sea. They passed Tissaeas Cape (v.462), Shepian coast 
(v.462) Skiathos isl. (v.463). They were following the eastern coast of Thessaly, when they discerned Mountain Olympus (v.466) they turned the boat to wide Pallene (v.468) -the first peninsula of present-day Chalkidiki-they passed the forestry Athos town (v.467) (which according to Claudius Ptolemy was built on the edge of present-day 3rd peninsula of Chalkidiki) and they reached Samothrace(v.468). Orpheus, as a priest, initiated the Argonauts in the obscure Kavirian Mysteries (v.469). They sailed from Samothrace to Lemnos isl. (v.474) where the Lemnian women, having killed all their husbands for their unfaithfulness, came together with the Argonauts, offering them the joy of love. And the Argonauts would have forgotten their mission if Orpheus hadn't convinced them with promising words (v.482-485). They left Limnos, entered the Hellespont straits (v.497) and stopped at the Artakian spring (v.496 todays Turkey town of Erdek). Kyzikos, the king of the region (v.503), welcomed them and offered them his hospitality. But during the night, wild thieves from the north region attacked their camp trying to kill the Argonauts (v.514-523). But the heroes- all excellent warriors- mainly with Hercules and his lethal arrows, killed them all (v.520-521). But due to the mist, Hercules killed the king Kizykos by mistake (v.525-526). They buried him with honors and continued their journey. But at the next stop near mount Arganthos (v.641, present Gemlik area) Hercules leaved Argo to hunt at the mountain and never came back. His nephew Ylas, tried to find him and bring him back to the ship but he was eventually kidnapped by the Limachides Nymphs and passed away (v.640-652).

The Argonauts lost their faith without the supernatural hero Hercules, but they continued their journey. According to Orpheus' description, they entered a narrow golf (v. 670-673) present-day Turkish Ismit bay), which is indeed narrow. They camped for one day, and after visiting Phineas (v.674) they continued their journey to the Cyanean rocks, present-day Bosporus straights. (v.681-713).

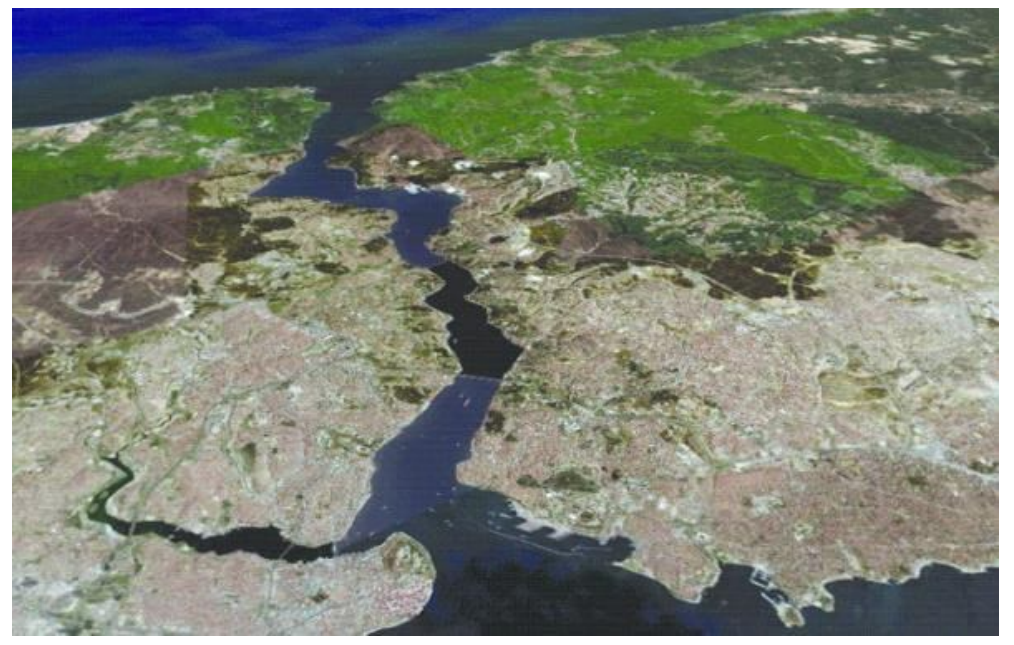

Figure2. Orpheus says that as they were crossing the "Cyanean Rocks", the coasts were hitting one the other. But this was a metaphoric expression. As we can clearly see in this aerial photo of Google Earth, Bosporus is a helical path, and whoever crosses it is mistakenly led to believe that the two coasts "collide" with each other, due to this natural perspective phenomenon.

They passed the tiny island of Thyneis (v.717) which exists until today at the coast of Cebeci city, in Kefken region. 


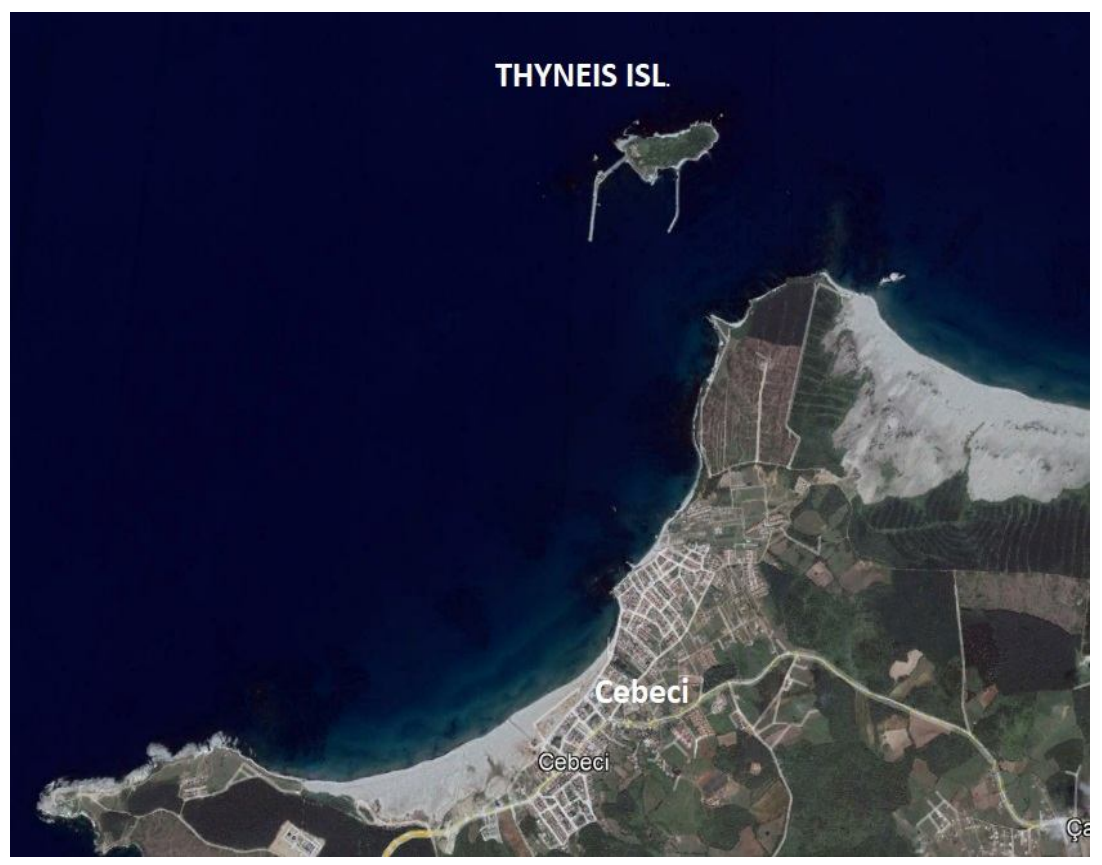

Figure 3. The tiny island, Thyneis (present Cebeci Island) that Orpheus refers to in the verse 717 as "Dolichi nessos" (i.e. meaning the rugged island) is real. This island is not marked in any map of Turkey due to its small size, but in the high magnification of Google earth, the Orphic Thyneis is revealed. It is the same island that Claudius Ptolemy refers to as Thynias or Dafnoussia.

After a few days, they arrived at the region of king Lykos who welcomed them and offered them his hospitality. Unfortunately, two Argonauts died there. It was Idmon and Tifys the captain, but fortunately for them, Agaeos the Pleuronian, another experienced member of the crew, became the new captain of Argo(v. 720- 732). They reached Paphlagonia (v.737) and passed two capes (v.736-738), an anonymous one (i.e. which is proved to be the Turkish Kiopekkayasi Burnu) and the Cape of Karamvia (i.e. the Turkish Kerempe Burnu which has kept the ancient root of the word Karamvia). Why was Karamvia (or Karambis) cape so important to the ancient sailors and referred by Orpheus with its name? Because it was the shortest route from the coast of Anatolia to the ancient Tauric Peninsula, present-day Crimea.

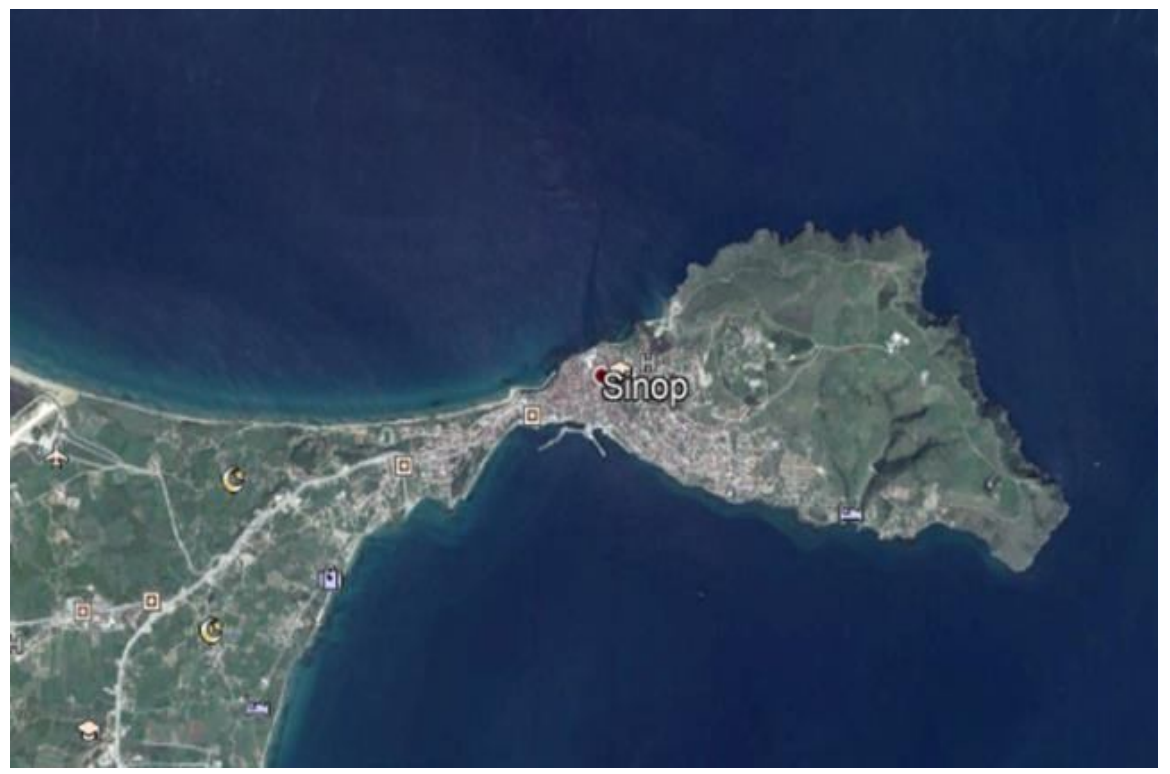

Figure 4. Orpheus (v.757) says that Argo passed by the "rough elbow" of Sinope. An amazing aerial photo of Sinope proves that the peninsula indeed looks like a "hand elbow", just like Orpheus calls it in a metaphorical way.

According to Orpheus, they passed Sinope peninsula and reached the land

of the Amazons and their capital Themiskyra (v. 741-744). The capital was located at the delta of river Thermodon and the Turks have kept the ancient Orphic name of the river and call it Terme. Finally, they arrived at Colchis, which is the present-day Georgian harbor of Poti. They entered river Phasis (v.762), present- 
day Rioni river, and "autica"(v.764), which means "instantly", they saw the palace of king Aeetes and the walls where the golden Fleece was guarded.

King Aeetes was very suspicious of the sudden visit and threatened the Argonauts with his enormous military power. But Medea, his beloved younger daughter, fell in love with Jason and helped them to steal the Golden Fleece. Five Argonauts, Orpheus, Jason, Mopsos, and the twin brothers Castor and Polydefkes (Pollux), escorted by Medea, entered the tower where the Golden Fleece was kept, and made the guards believe they were visitors. Medea $\&$ Orpheus used their botanic knowledge, burned some hypnotic weeds and the guards fell asleep. They stole the Golden Fleece and hurriedly returned to Argo which was well hidden in an area of Phasis riverbank full of canes (v.890-1025).

But prince Apsyrtos, the younger brother of Medea, who was meanwhile seeking his sister, visited Argo with his guards. When he realized what had happened, he attacked the Argonauts but had no luck with the heroes. They killed him and his soldiers, but due to the luck of time, they did not burry him like a prince deserved, but threw his body into the river (v. 1026-1038). This unsacred act will hunt the Argonauts during their entire Journey, until later when Orpheus relieves them from the murder of Apsyrtos with his prayers.

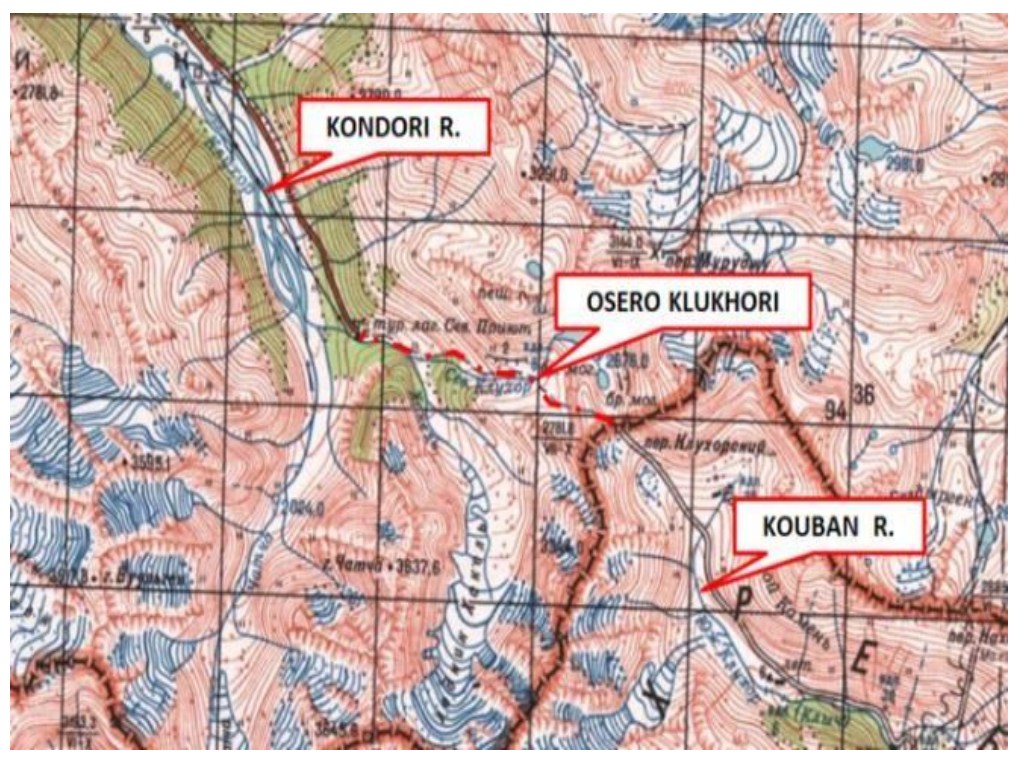

Figure 5. Osero Klukhori, or Kluchori passage. The ancient «diolkos» located at a height of $2500 m$ through which the Argonautspassed Argo from the West to the East Caucasus in safety. This passage used to connect the springs of two ancient rivers (i.e. now Kondori and Kouban) ,thus helping the uninterrupted communication and transportation of people and goods at both sides of Caucasus. In the ancient text the passage (Diolkos) is referred to as "Narrow Erytheia"

They entered a river backwards (i.e. presently the river Kondori) and reached mount Caucasus. There, they passed Argo with the help of Sindi (i.e. the habitants of the Caucasian canyons), by pulling the boat through an ancient passage (i.e called "narrow Erytheia") to the eastern side, at another river, which is the ancient Saranges river according to Orpheus (v.1055), the present-day Kuban river of Russia. They reached Maeotis lake (v.1057) (i.e. the present-day Azof sea) and after three days of rowing (v.1059), they crossed the Bull's passage (v.1059) the present-day Crimean isthmus and reached the entrance of the ancient river Borysthenes (v.1070) (i.e the present-day Ukrainian Dnieper). After 10 days (v.1083), they reached the Cronian sea (v. 1085), (i.e. the present-day Krementsuk lake) and six days after that, they arrived at the marshes (v.1090-1094). This region was the Pripyat marshes, known since ancient times as the largest marches of the world. The river was 
shallow at the time and the Argonauts disembarked from Argo and used ropes to pull the ship from the coast. They finally reached another floating river which is today known as Pripyat. This river is connected to the rivers Western Bug and Vistula, creating the ancient amber route, a commercial river road extending from the ancient coast of Ukraine to the coast of Poland.

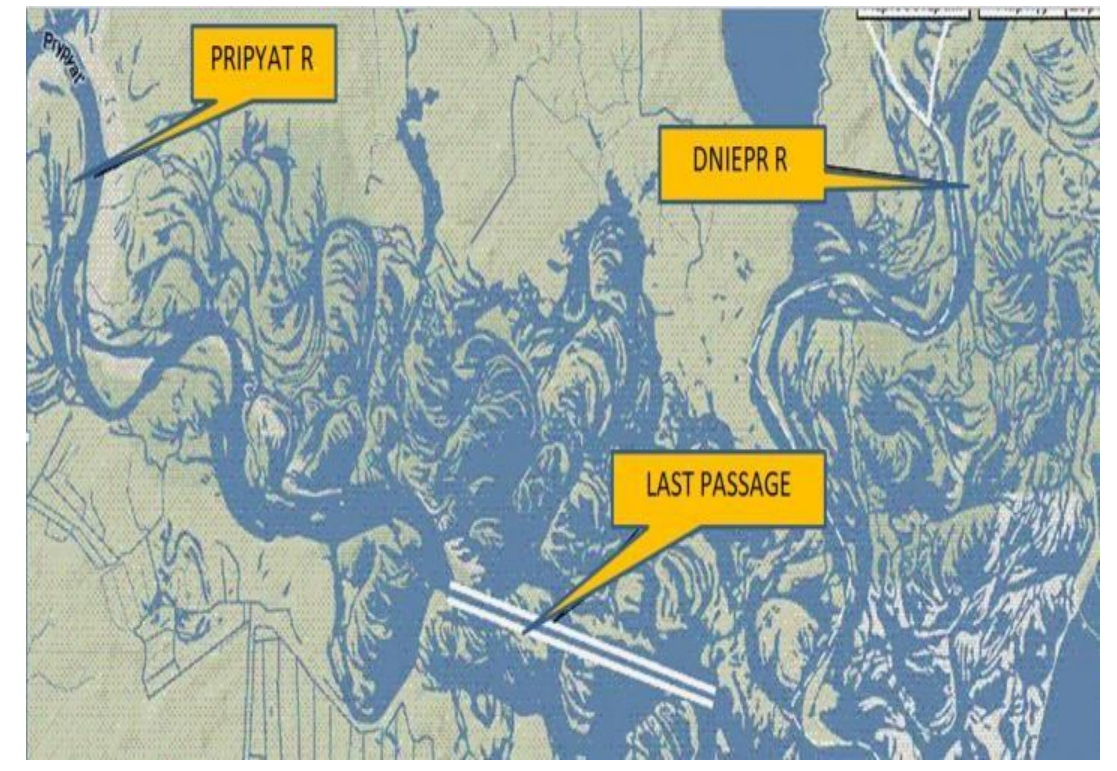

Figure 6. After 16 days of rowing (i.e. $\quad$ v. $1083=10$ days \& v. 1110=6 days), the Argonauts arrived at the marshes, which are the present-day "Pripyat Marshes" with certainty. Despite the fact that during that ancient period of time the two rivers were not directly connected to each other like they are today, thanks to the seasonal flood, the Argonauts disembarked from the ship and managed to carry Argo with ropes through the "Neiaton Kefthmona", translated as the "last passage".

But the Argonauts did not intend to complete the amber route (i.e. which was ending at the present Polish port of Gdansk). Their destination was the Nether Hermioneia (i.e. present Holland) and in order to avoid the big obstacle of the Danish Peninsula, when they reached the ancient area of the present Polish city of Bydgoszcz, they turned west, entering an ancient floating river (present Warta), which guided them to the heart of the ancient Germany. They passed the rivers which are now known as Oder and Havel and they finally entered the large floating river Elba.

After certain days of rowing passed, they came out to the open sea (i.e. the today North Sea, near the city of Cuxhaven). After Colchis, their destination was The Nether Hermioneia, which means the nether land of god Hermes in Greek, which is the present-day Netherlands. 


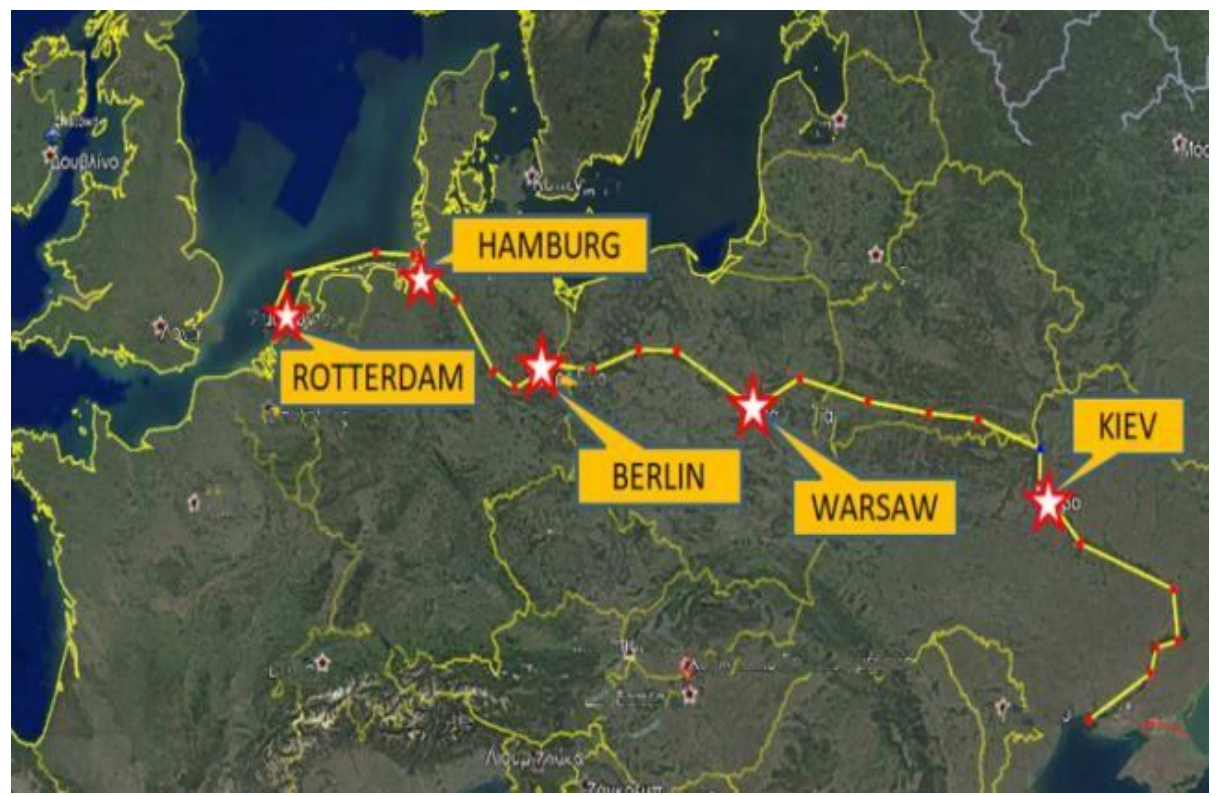

Figure 7. The exact route from Pripyat marshes (north of Kiev) through the ancient floating rivers of Central Europe (i.e. Pripyat, West Bug, Vistula, Varta, Oder, Elba and other smaller rivers), the final destination being the Nether Hermioneia, the modern Netherlands.

After exiting to the sea (i.e. presently the North Sea), they passed Acheron River (v.1137). Orpheus mentions that this river contains isolated springs, crosses a cold area and throws its water to a dark lake (v.1138). Indeed, river Rhine=Acheron has its springs $1300 \mathrm{~km}$ away on the Alps, crosses the cold planes of presentday Switzerland and throws its water to a lake which has dark waters up to this day, called the lake of Constance.

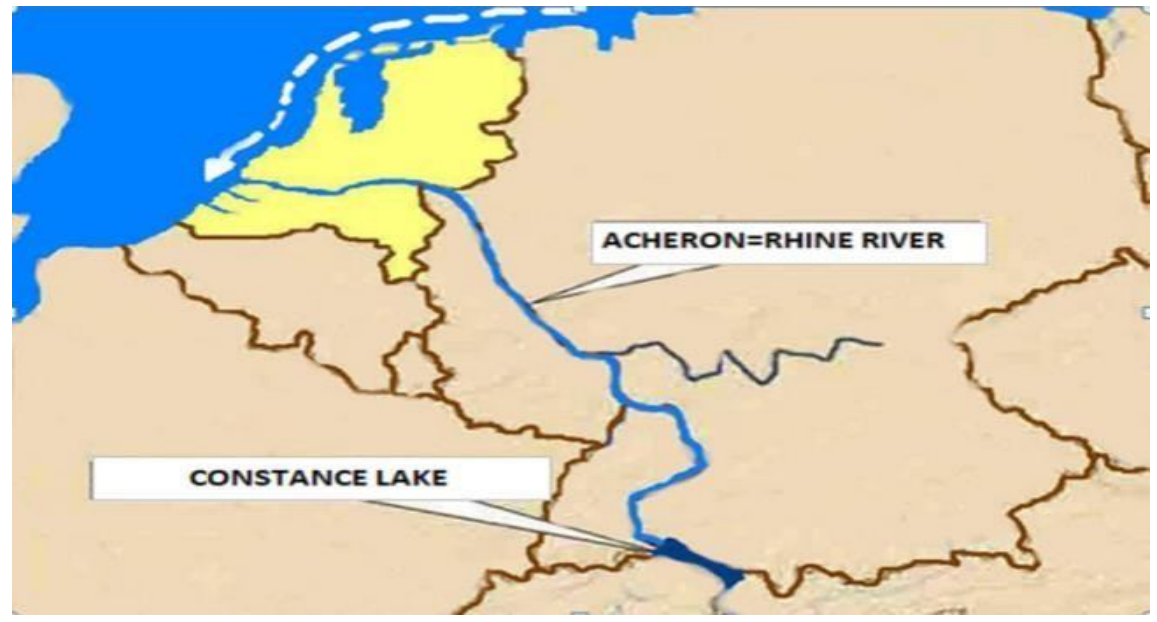

Figure 8. According to Orpheus, the ancient Acheron River had a faraway spring, and its water used to fall into a "dark" (kelaini) lake. (v.1136-1137). This is an amazing geographical information which is true.

They remained there for a few days, doing business with the fairest people (v.113) as Orpheus emphasizes, buying precious goods, rare in the Mediterranean region, with gold.

When they left the ancient country, they passed Iernides islands (v.1171) which is the ancient name of the British islands. Iernis means the "land of Ier". Up to this day, one British island has kept its ancient Orphic name, translated into English: Ireland. Argo faced a horrible thunderstorm with strong winds and sea currents (v.1186-11194), phenomena very common in the present-day English Channel. After leaving the English Channel behind, they crossed the coasts and the holly capes (v.1172) of ancient France and entered the "interior" bay with the indomitable sea (v.1173), as Orpheus describes. Indeed, the Biscay Bay is interior (i.e. semicircle), confirming the description of Orpheus. 
They continued their journey and when they reached the southern area of present-day Portugal, instead of entering the Gibraltar straits, they continued their journey for 12 days (v.1190) in the open Atlantic Ocean. Finally, Lygeas, the observer of the crew, saw the island of Queen Demeter in the distance, crowned with clouds (v.1193-1195).

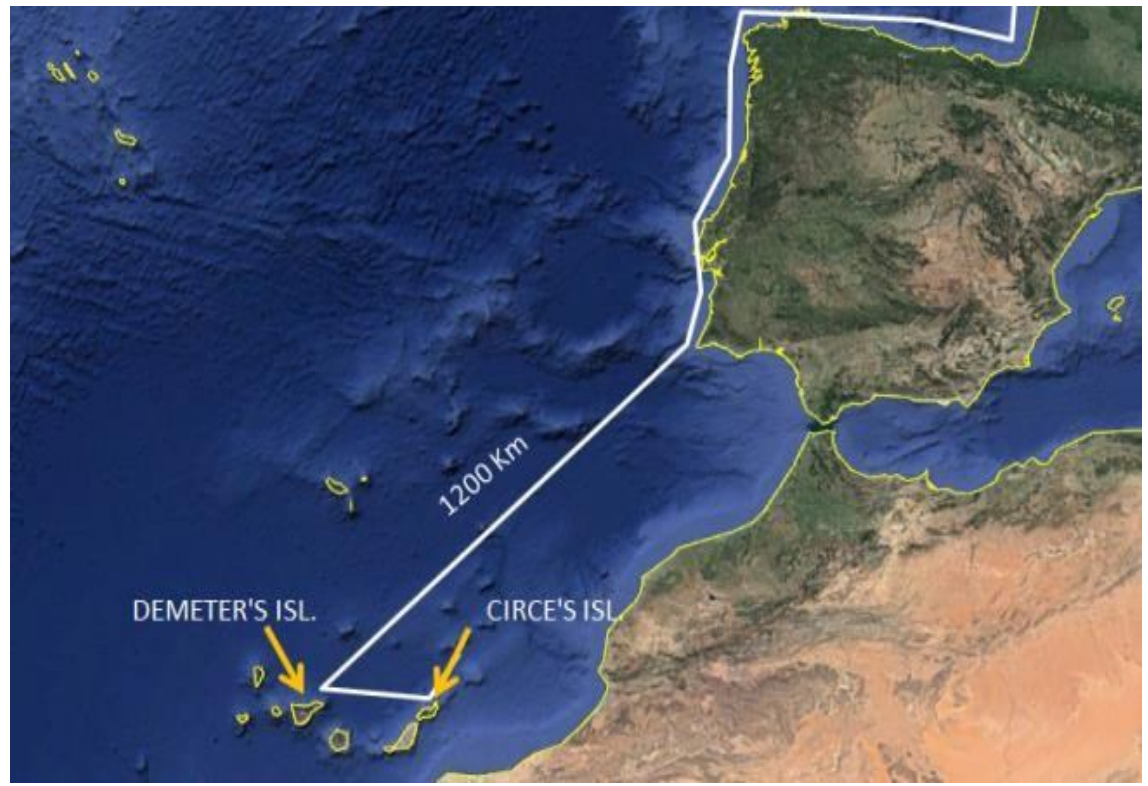

Figure 9. After leaving the south coast of Portugal, they travelled 12 days in the open ocean (v.1190). The average speed of Argo in the open sea was $\sim 100 \mathrm{~km} /$ day. Indeed, the distance between Portugal and Tenerife Isl. is $\sim 1200 \mathrm{~km}$ or 12 days of rowing. Demeter's island= Tenerife, Circe Island $=$ Fuerteventura .

As a matter of fact, the present-day Spanish island of Tenerife is situated $\sim 200$ kilometers away from Portugal or 12 days of rowing (i.e. the mean speed of Argo in the open sea was

$\sim 100 \mathrm{~km} /$ day). This island is normally covered with clouds for many days during the year due to the microclimate of the enormous volcanic mountain of Teide, thus confirming Orpheus who says that the island was "crowned" with clouds.

Orpheus also makes a note of the famous "sweet fruits" of the island (v.1207), meaning the bananas, which Tenerife Island is famous for since ancient times.

The Argonauts avoided the (northern) sunny coasts because they were cliffy (v.1208-1210), as Orpheus had suggested. Orpheus' description of the characteristics of the island Tenerife is unbelievable. The northern coasts of Tenerife are truly rocky, and they lack a natural harbor.

Orpheus ordered the captain to turn the boat left (v.1210) and after 3 days (v.1212) or 300 kilometers, they finally arrived at their destination.

The island of Queen Circe (v.1212)-who was the sister of king Aeetes and aunt of Medea-is geographically the present-day island of Fuerteventura.

Circe already knew about the death of her cousin Apsyrtos (v.1232-1234) and did not want to accommodate them in her palace. She compassed the Argonauts and provided them meat, wheat and wine (v.1242-1245), asking them to leave her island. The Argonauts left the island and passed to the coast of Africa. As clearly stated by Orpheus, before reaching the Hercules Pillars, they passed the delta of Tartessus River (v.1248). Tartessus the "ghost" city, was built in the 
Tartessus riverbank, a few kilometers away from the coast, and vanished from the face of earth suddenly in the 6th BC century. Today, this area is identified as the river Marhar -Tahadart of Morocco, near the city of El Khaoucha. Orpheus proves that the ghost city of Tartessus was never built in Spain, at the coast of river Guadalquivir, but had always been situated in Morocco. This is why the archaeologists have never identified the location of Tartessus in Spain. To put it simply, according to Orpheus, the city was about 110 kilometers more southern from its theoretical location. They entered the Hercules Pillars (v.1249), which according to the right interpretation, means the "Hercules Lighthouse".

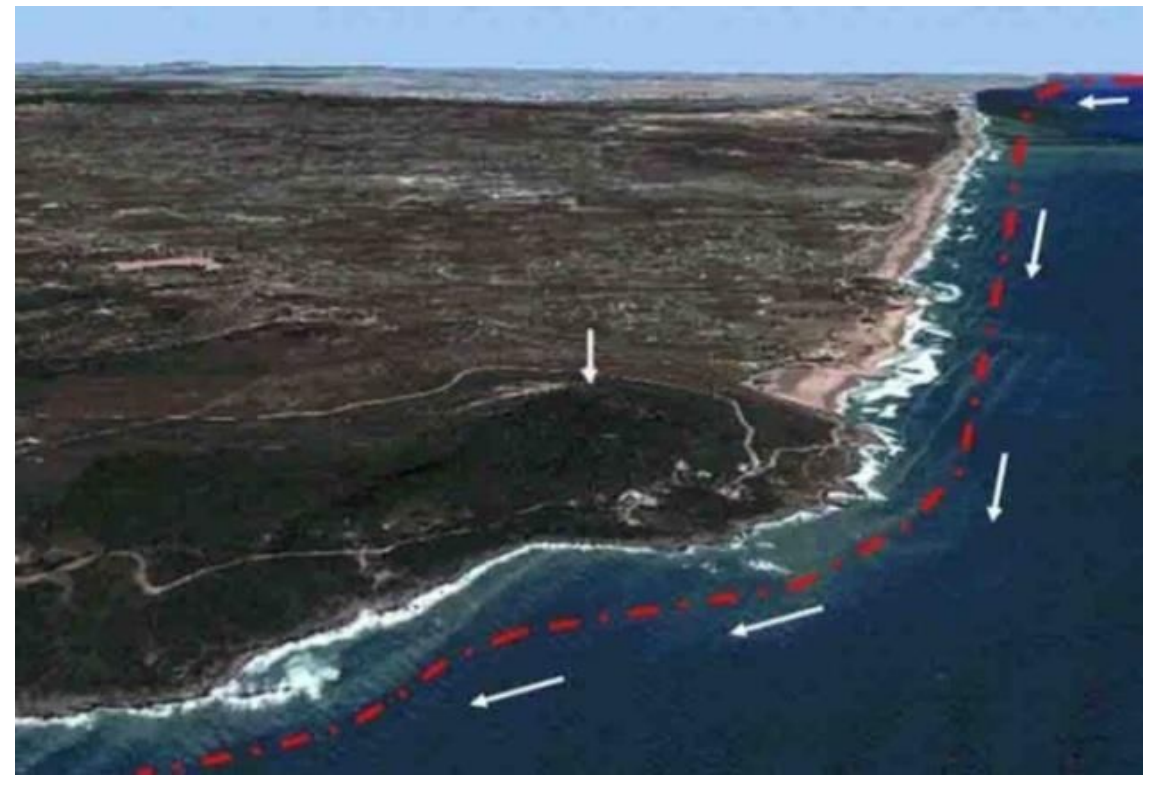

Figure10. The exact location of the Hercules Pillars (white arrow). The hill at the NW edge of Morocco. The ancient lighthouse which used to orientate the edge of Africa \& Europe and the beginning of the Atlantic adventure: The voyages to America!

The "Hercules
Pillars", con-
structed by Hercu-
les were in fact an
ancient lighthouse built on the top of a unique hill western of Tangier (i.e. close to the present Spartel promontory) thus orientating the end of Europe and the beginning of the Atlantic adventure.

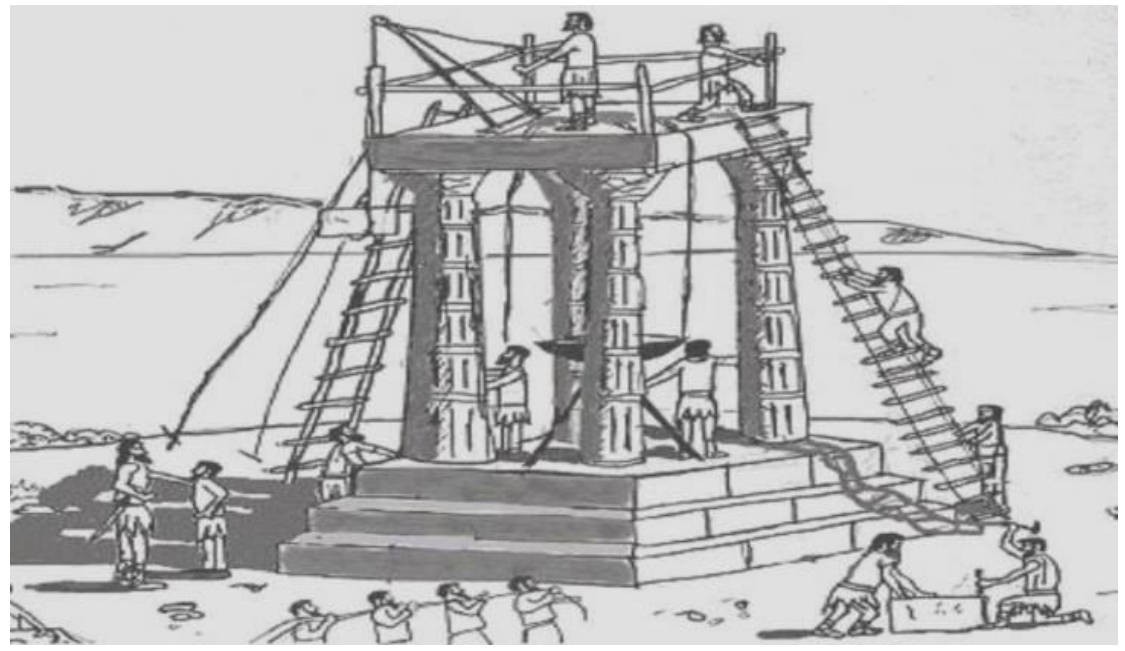

Figure11. The Hercules Pillars, in an artistic illustration designed by me. The most important lighthouse of that era.

They stayed a few days at the holly capes of Dionysus to rest (v.1250)- present-day north Morocco-and when they reached a certain place (somewhere in ancient Tunisia), they travelled north, crossing the Sardinian Sea (v.1250). They turned east, and after they passed the Ausonian Islands (v.1255)- outside the present-day golf of Naples- they reached the Tyrrhenian coast (v.1255), the present-day coast north of Naples. 


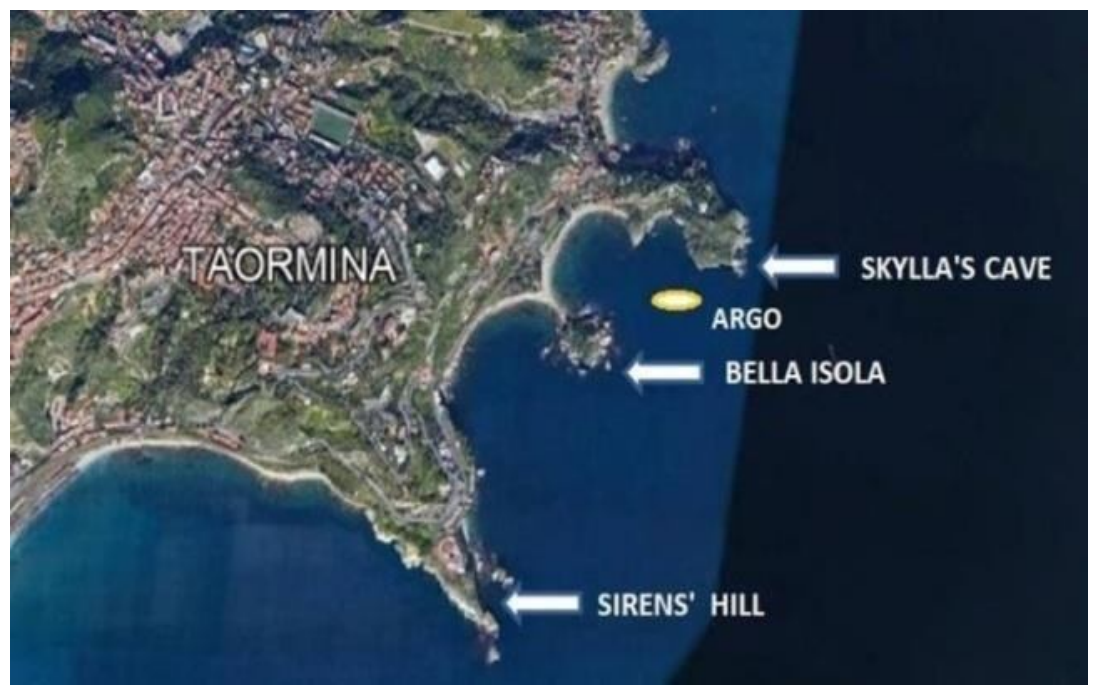

Figure12. An incredible aerial view from Google Earth verifies the ancient text and its precise description for this location, 4000 years later. The Scylla cave, (now Grotta Azzura), the small anonymous island connected to the shore, where they anchored Argo (now Bella Isola) and the Siren's hill (now Capo Taormina) exist up to this day at the east coast of Sicily, near the city

of Taormina, an ancient Greek colony.

They continued south, passed the Lilybaeum straits, the present-day strait of Messina (v.1256). After passing Scylla (destroyed v.1274 which I have restored) and Charybdis (v.1260), they reached the port of Sirens (v.1277) According to Orpheus, the harp holding and superbly singing Sirens were not man eater monsters. They were the "hot" erotic women (i.e. Sirius means "Hot" in the ancient Greek), a kind of prostitutes that tried to attract the exhausted sailors with their charms and make them forget their homes.

But Orpheus with his songs managed to cover the attractive songs of Sirens who were calling the sailors to their love (v.1283-1297). They left the port of Sirens towards the Island of Corfu/Kerkyra (v.1301) and the kingdom of Phaeacians.

King Alkinoos and queen Arete welcomed them to the palace. Meanwhile, the fleet of Colchis had arrived with a lot of soldiers seeking for Medea to bring her back to her father to be punished for the murder of her brother. But Jason married Medea in time on board of Argo and thus the Kings of the island refused to surrender her to Colchis' army, since they did not want to separate a married couple and thus disrespect the holly act of marriage (v.1304-1352).

The Argonauts left Kerkyra (i.e. Corfu) but when they reached the southern coast of Peloponnese, instead of turning east to Iolkos, they continued until the port of Sidra (Syrtis is referred in v.1355) the ancient harbor at the coast of Africa, in Libya.

They stayed there for a couple of days, but unfortunately Kanthos-another Argonaut- died (v.142-144). They left Sidra to Crete (v.1354), but they could not reach the Cretan harbors due to the copper "triple-giant" (i.e. Talos) that used to throw stones to hostile ships, thus preventing them from approaching the coast (v.1355).

From this interpretation we can easily understand that Talos was a kind of giant copper catapult and not a robot like many scholars assume. They continued to Anafi (v.1366), the island that appeared when Apollo threw his sparrow from Delos (i.e. this is the meaning of the word Anafi). Before Anafi, they passed two tiny islands that exist until today, the "Melantian Rocks" (v.1363). 


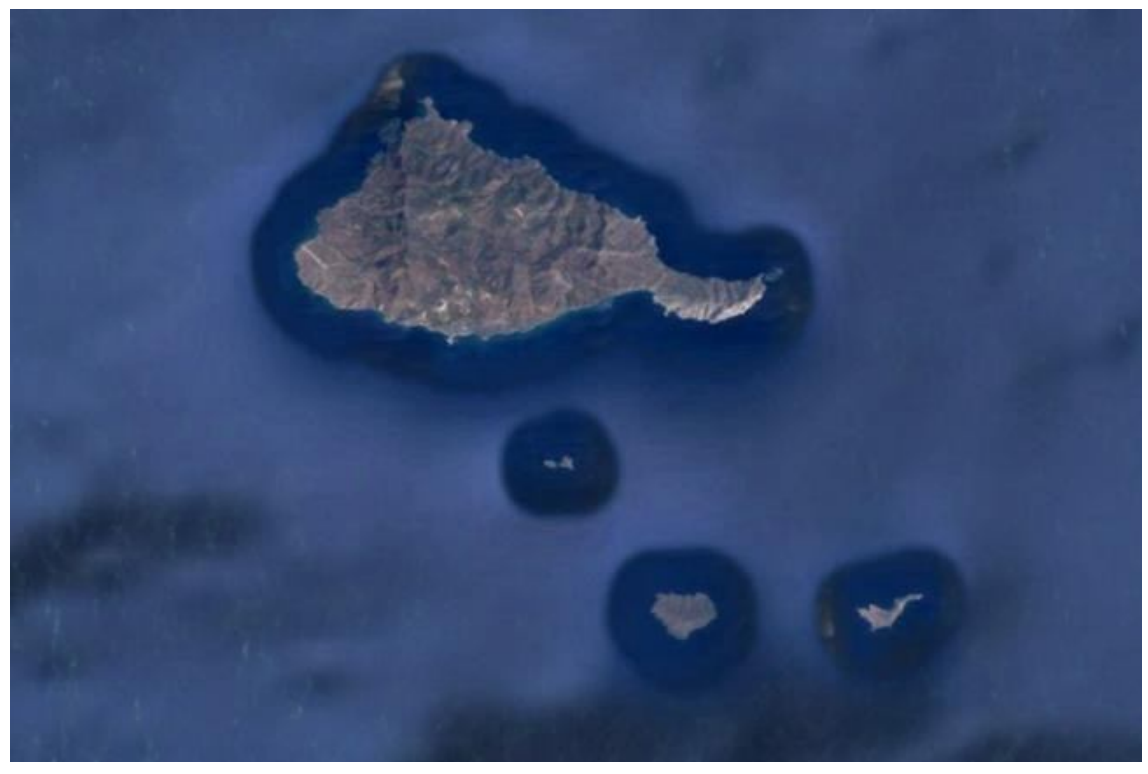

Figure13. An amazing geographical information. The "Melantian Rocks", the two small islands south of Anafi (i.e. known only to local people) exist up to this day, proving that the Argonauts passed by them.

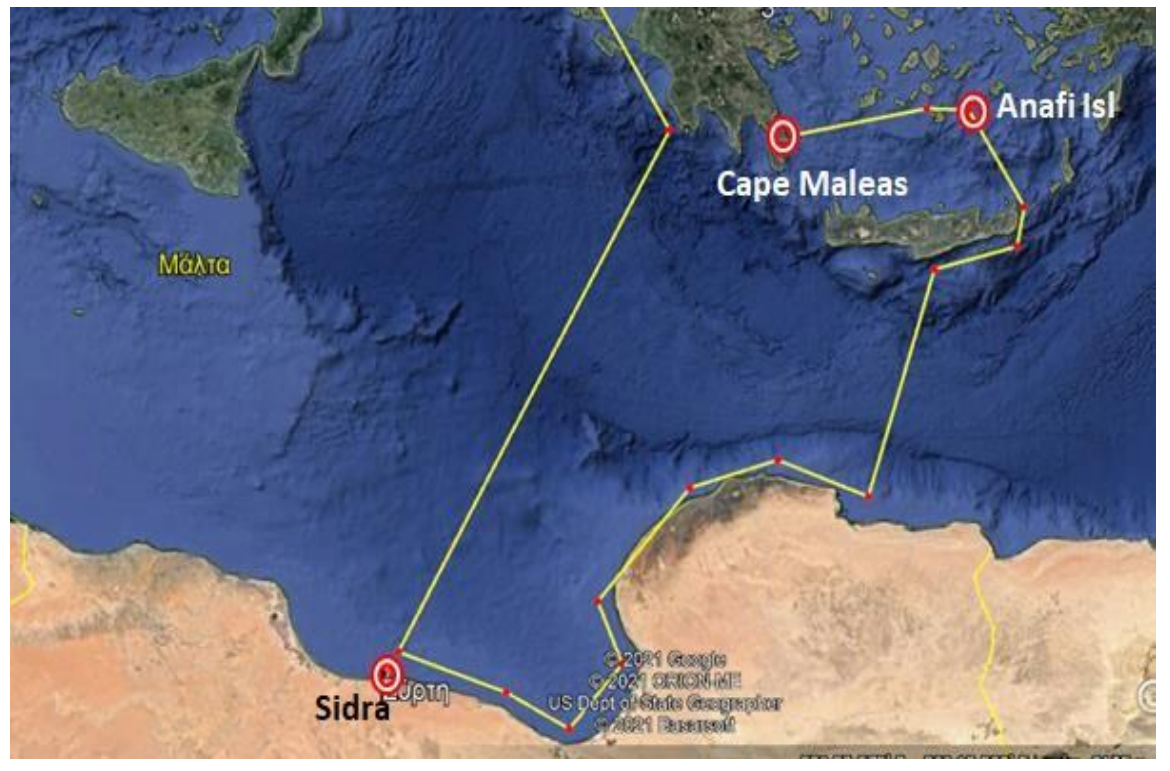

Figure14. The last part of the expedition in the Mediterranean Sea. From the south coast of Peloponnese, they continued to the ancient port of Syrtis (Sidra), where unfortunately another Argonaut was killed. They sailed to Crete and then to Anafi Island. The final destination was the Cape of Maleas where Orpheus disembarked from Argo.

They continued rowing until the cape of Maleas (v.1371), where Orpheus disembarked. He continued until Tainaron Cape (v.1378), where he executed purifications to the Gods in order to wash away the blood of Apsyrtos' murder.

The Argonauts continued rowing until they reached Iolkos to which they arrived 16 months later, after having covered 19000 kilometers. The triumph of Prince Jason, Medea and the Argonauts was completed with an astonishing welcoming by the people of Iolkos.

Orpheus after finishing the purifications at Tainaron, returned to the snowy Thrace (v.1381), his homeland. He then entered the cave where he was born by his beloved mother (i.e. Calliope) and Oeagrus, his majestic father (v.1383). 


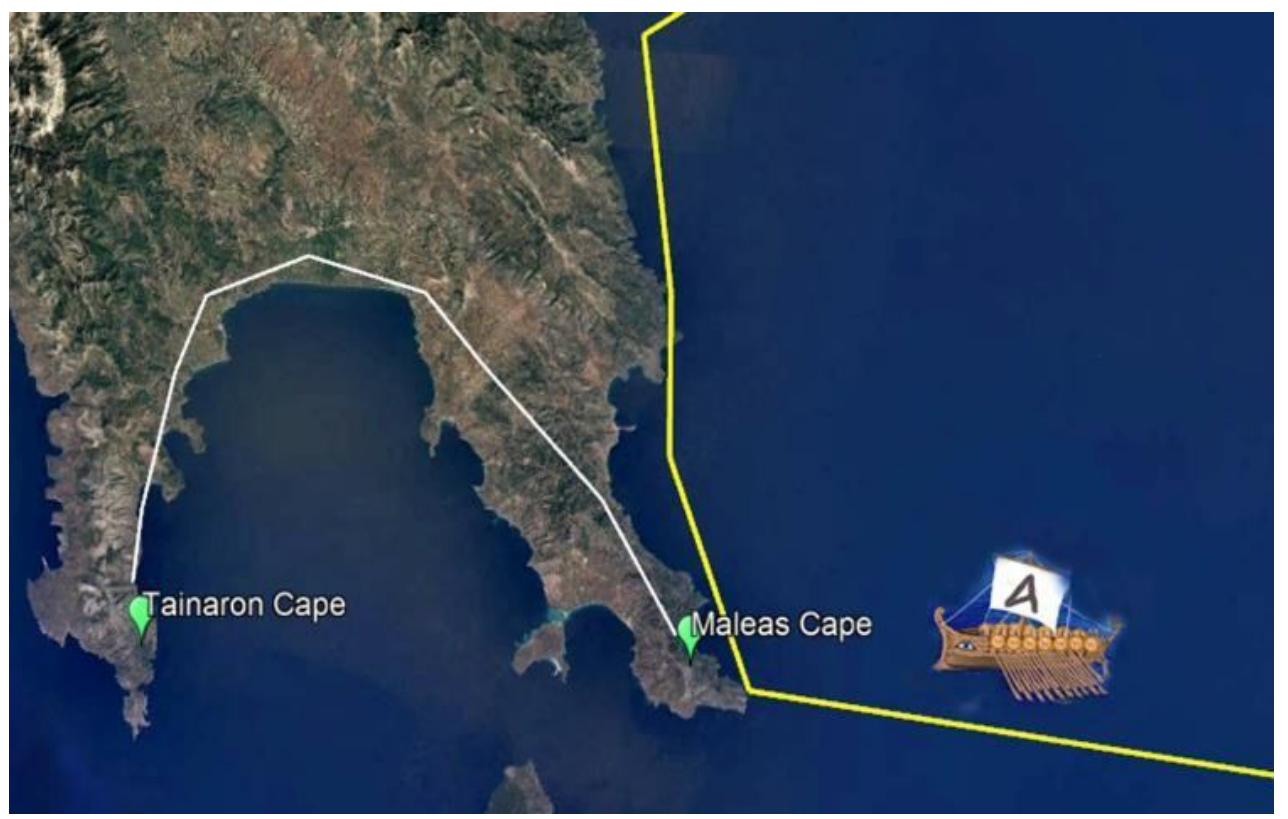

Figure15. Orpheus disembarked from Argo at Maleas Cape (i.e. located at the eastern peninsula of Peloponnese). $\mathrm{He}$ headed to Tainaron Cape to perform the cleansing rituals which would purify the Argonauts from the blood of the murdered prince Apsyrtos. According to ancient Greek writers, the "Gate of Ades" (i.e. a holly place with which Orpheus, as a great priest, was familiar) was at Tainaron.

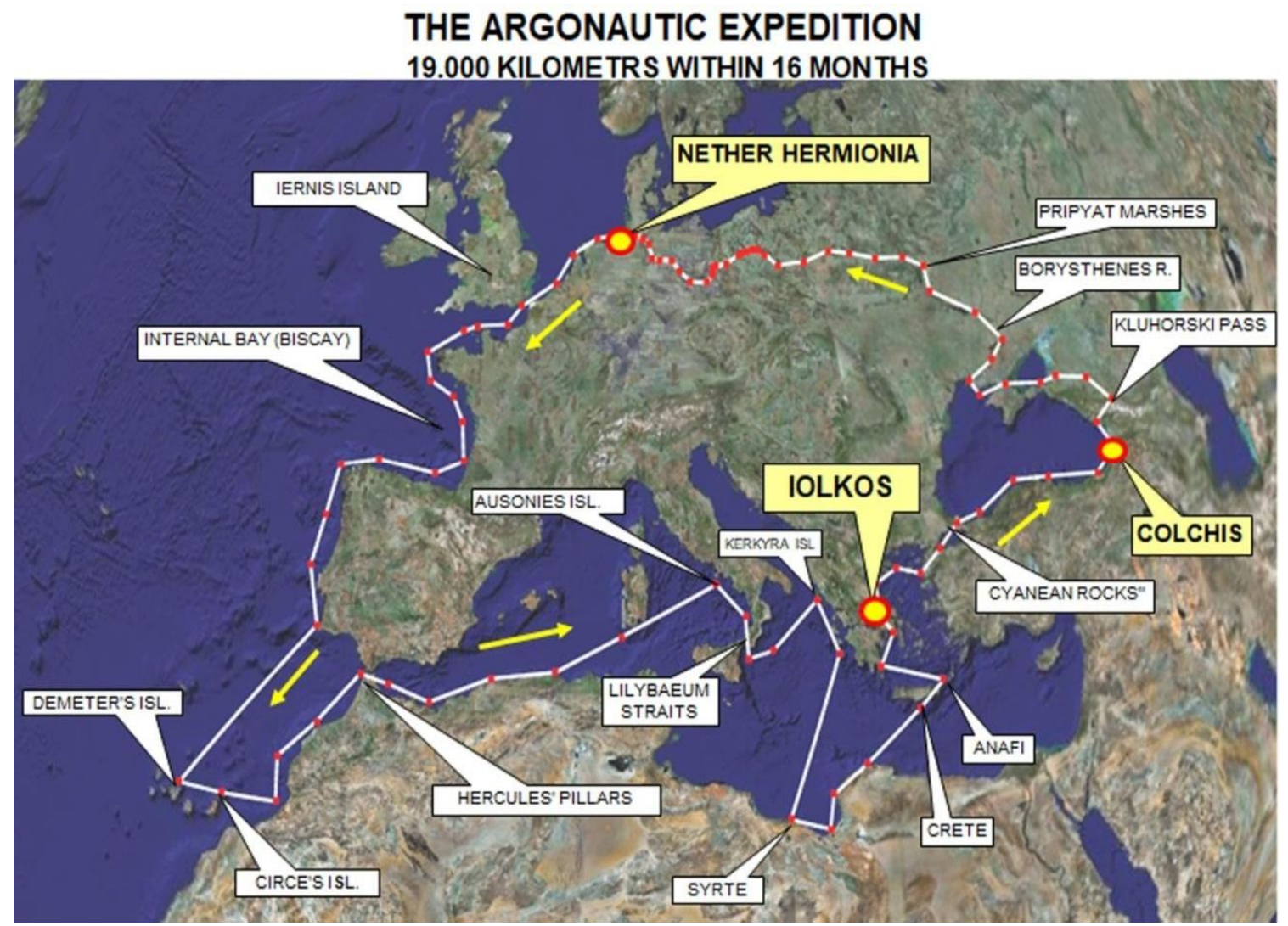

Figure16. The unprecedented Argonautic expedition. The exact route followed by the Argonauts from Iolcos to Colchis, Nether Hermionia through the Amber Route, Iernis Isl (Great Britain), English Channel), Internal Bay (Biscay), Demeter's island (Tenerife), Circe's island (Fuerteventura), Africa, Hercules pillars (Gibraltar), Sardinia, Ausonies islands, Lilybaeum straits (Messina), Corfu, Syrte (Sidra), Crete, Anafi, Maleas cape and finally back to Iolkos. An incredible achievement of $19000 \mathrm{~km}$ (i.e. measured with the measure tool of Google Earth) within 16 month (i.e. calculated indirectly from the ancient text), a world record of rowing, never before recorded in the historical books. 


\section{REFERENCES}

[1] Sofias Sotiris, Orpheus\& Argonautic expedition, (2009)

[2] Sofias Sotiris, Orpheus Argonautica (2010), Modern translation

[3] Orphica, Pyrinos Cosmos publications

[4] Orphica, Passas Ioannis, Helios Publications

[5] Homeric Dictionaryby Konstantinos Papageorgiou of the publications Entos

[6] Encyclopedic Dictionary of Greek Mythology by Dimitris Krinelos

[7] Greek Mythology-Trojan War of Ekdotiki Athens

[8] Historian Atlas Dimitrakou-Karolidou volume A '

[9] Claudius Ptolemy "Geographical Analysis" by A. Angelopoulos

[10] "Greek History" magazine of March-April 2005 and September-October 2005

[11] Homer Iliad, translation I. Polylas

[12] Homer Odyssey, translation A. Ephtaliotis

[13] Google Earth Atlas Encarta of the world by Microsoft

[14]

Citation: Sofias Sotirios. "Orpheus' Argonautica: The Voyage of the Argonauts

Copyright: (c) 2021 Sofias Sotirios. This is an open-access article which permits unrestricted use, distribution, and reproduction in any medium, provided the original author and source are credited. 